\title{
OPTIMIZED CHARACTERIZATION OF GAS CHIMNEYS BASED ON SPECIAL SEISMIC PROCESSING
}

\author{
José Paulo de Melo Goulart ${ }^{1}$, David Lopes de Castro and Wander Nogueira Amorim ${ }^{3}$
}

\begin{abstract}
A new computational methodology was developed to facilitate the interpretation of gas chimneys in seismic sections by analyzing the frequency spectrum of the seismic signal in the Hilbert Domain. Gas chimneys are structures associated with the migration of hydrocarbons or free gas, causing vertical chaotic disturbances in the seismic data. Its occurrence in oil reservoirs is considered an important indicator of the presence of an active petroleum system and its mapping is useful to reduce exploratory risks, increasing the probability of success of the pioneer wells. Standard seismic processing does not favor the recognition of gas chimneys, since their characteristic seismic signature is treated as noise and the low frequency is strongly attenuated already in the period of the seismic acquisition. The set of reflections is calculated to enhance the low frequencies of the seismic signal, making the gas chimneys easily identifiable in the seismic sections where they were not previously even perceived. The special processing flow was applied to seismic data from the Parnaíba Basin (NE Brazil). This Paleozoic basin is especially rich in gas chimneys, which were favored by transcurrent tectonics associated with the Transbrasiliano Lineament. The gas chimneys interpretation could be validated by the observation of correlated seismic, topographic and geochemical features.
\end{abstract}

Keywords: special processing, petroleum system, exploratory risk, Parnaíba Basin.

RESUMO. Uma nova metodologia computacional foi desenvolvida para facilitar a interpretação de chaminés de gás em seções sísmicas por meio da análise do espectro de frequência do sinal sísmico no Domínio de Hilbert. Chaminés de gás são estruturas associadas à migração de hidrocarbonetos ou gás livre, provocando perturbações caóticas verticais no dado sísmico. Sua ocorrência em reservatórios petrolíferos é considerada um importante indicador da presença de um sistema petrolífero ativo e seu mapeamento é útil para reduzir os riscos exploratórios, aumentando a probabilidade de sucesso dos poços pioneiros. 0 processamento sísmico padrão não favorece o reconhecimento das chaminés de gás, uma vez que sua assinatura sísmica característica é tratada como ruído e a baixa frequência é fortemente atenuada já no período da aquisição sísmica. 0 conjunto de reflexões é calculado para realçar as baixas frequências do sinal sísmico, tornando as chaminés de gás facilmente identificáveis nas seções sísmicas onde antes não eram nem percebidas. 0 novo fluxo de processamento foi aplicado em dados sísmicos da Bacia do Parnaíba. Esta bacia paleozoica é especialmente rica em chaminés de gás, cuja presença foi favorecida pela tectônica transcorrente associada ao Lineamento Transbrasiliano. As chaminés de gás interpretadas puderam também ser validadas pela observação de feições sísmicas, topográficas e geoquímicas correlatas.

Palavras-chave: processamento especial, sistema petrolífero, risco exploratório, Bacia do Parnaíba.

Corresponding author: José Paulo de Melo Goulart

${ }^{1}$ Universidade Federal do Rio Grande do Norte, Campus Universitário, Rua das Engenharias s/n - Lagoa Nova, 59078-970, Natal, RN, Brazil - E-mail: paulo.goulart404@gmail.com

2Universidade Federal do Rio Grande do Norte, Centro de Ciências Exatas, Departamento de Geologia. Campus Universitário - Lagoa Nova, 59072-970, Natal, RN, Brazil-E-mail: david@geologia.ufrn.br

${ }^{3}$ Cimageo - Central de Imageamento Geofísico, Travessa Augusto Leite, 10, Tirol, 59020-370, Natal, RN, Brazil - E-mail: wander@cimageo.com.br 


\section{INTRODUCTION}

Despite the extraordinary technological advances of the last decades, the failure rate of oil well drilling still remains high, especially in new exploratory frontiers of poorly known sedimentary basins. The mapping of geological features indicating the presence of hydrocarbons in seismic data is a fundamental condition to increase the discovery potential of new oil reservoirs. In this context, Gas Chimneys (GCs) are associated with upward migration of fluids and have being considered an important hydrocarbon indicator (Heggland, 1998; Ligtenberg, 2005). Their studies may often have applications such as establish the migration path, distinguish between charged and non-charged prospects or sealing versus non-sealing faults, thereby achieving a reduction in exploratory risk (Aminzadeh et al., 2001). Another problem that can be solved by the study of the gas chimneys of a frontier basin is a better definition of the petroleum systems, confirming areas of possible hydrocarbon generation where previously there were only doubts.

The GC causes vertical disturbances of the seismic response, characterized by low amplitudes, low trace-to-trace similarity and lateral discontinuity of the reflections (Fig. 1). This typical seismic signature is not highlighted in standard seismic processing and is often treated as noise to be eliminated from seismic data with new processing steps (Aminzadeh et al., 2002). This work presents a new processing technique that enhances the GCs in the seismic sections, extrapolating the frequency spectrum of the seismic signal from the Hilbert Transform and makes a comparison with the processing technique known as Pre-Stack Time Migration (PSTM). This technique was applied in seismic data from the Parnaíba Basin (NE Brazil), revealing a substantial number of gas chimneys and, thus, considerably increasing the exploratory potential of this new frontier basin.

\section{GEOLOGICAL CONTEXT}

The special processing for gas chimney enhancement was applied to seismic data from the Parnaíba Basin, which is located in the northeast region of Brazil and occupies an area of about 670,000 km² (Cordani et al., 2009; De Castro et al., 2014). This is a Paleozoic intracratonic basin, although Mesozoic deposits occupy large areas (Mesner \& Wooldridge, 1964). The maximum thickness of the sedimentary basin turns around $3,500 \mathrm{~m}$ in its depocenters. However, rifts systems of Cambrian-Ordovician reach depths of $4500 \mathrm{~m}$, buried by Silurian to Early Triassic tectono-depositional sequences (De Castro et al., 2016). It is regarded as an exploratory frontier basin, considering its extensive area and the small volume of oil research activities so far developed. The diabase sill acts as the main constructor element of the hydrocarbon traps, sealing the accumulations of the known gas fields (Cunha et al., 2012).

\section{METHODOLOGY}

\section{Seismic Processing to Optimize the Identification of Gas Chimneys}

The lack of knowledge of the presence of GC in the studied area is often the reason that seismic processing geophysicists try to force too much coherence filters in the seismic data to overcome the lateral discontinuity of the reflectors caused by gas circulation. In some cases, seismic sections show an abrupt loss of the excellent quality of their reflectors in their shallow part, becoming completely chaotic, whereas the deeper reflectors remain with their good continuity (Fig. 1), proving that there are no problems with the parameters used in the acquisition and processing stages of the seismic data. In many cases, the degraded seismic response is due solely to the presence of $\mathrm{GC}$, as pointed out in Gulf of Mexico and West Africa basins (Aminzadeh et al., 2001). Therefore, it is necessary and important that the professionals involved in seismic processing are aware of the presence of GC in their work area.

Many efforts in seismic processing have been devoted to solving the problem of quality degradation and filtering the impact of gas chimneys on seismic sections (Dunbar et al., 1998; Englehart et al., 2001). In addition to the filtering techniques, tomography, seismic acquisition of shear waves and neural network that combine the use of different seismic attributes with this purpose (Aminzadeh et al., 2002). The procedures suggested here seeks, differently, to highlight the visualization of the GCs. Therefore, a special processing flow is proposed to improve GC visualization, based on spectral filters aimed at the enhancement of low and high seismic frequencies, which highlight characteristic patterns of these desired structures. They are called Low Frequency Enhancement (LFE) and High Frequency Enhancement (HFE).

The High and Low Frequency Enhancement technique is an alternative to optimize the identification of subtle geological features in seismic data. Techniques to enhance high frequencies are commonly employed in the mapping of sub-vertical fault slip, reflection terminations or even flat spots, as they allow an increase in the vertical resolution of the seismic sections (Bhandari \& Cividin, 2008). In contrast, the amplification of the low frequencies can be done to emphasize sub-vertical discontinuities, like faults or even to highlight more clearly the lack of reflections, as in the case of GCs. 


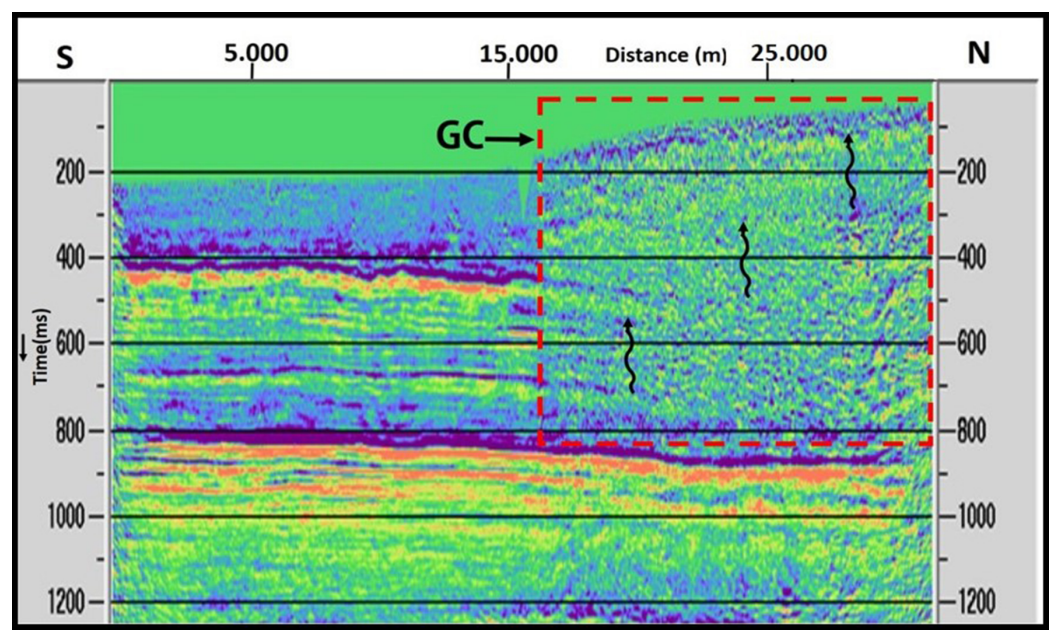

Figure 1 - Seismic section showing a $12 \mathrm{~km}$ wide GC (red rectangle), with abrupt loss of quality of the shallow reflectors, while the deeper ones (> $800 \mathrm{~ms}$ ) maintain intact their lateral continuity.

It is well known that the frequency spectrum of the seismic signal has limited bandwidth both for low and high frequencies (Bulhões \& Amorim, 2005). At low frequencies, the limitation has two main reasons: a) the geophones and hydrophones do not respond adequately to frequencies below 6 to $8 \mathrm{~Hz}$. In addition to introducing a significant phase distortion, the amplitudes in this environment are greatly attenuated; and b) the low frequencies are very affected by the surface noise, which is very rich in this frequency range, especially in the Brazilian sedimentary basins. At high frequencies, the frequency spectrum limitation of the seismic signal has another reason. Sedimentary rocks have little elasticity and the propagation of seismic waves causes friction between adjacent grains and crystals, and seismic energy quickly turns into heat (absorption effect). This effect is greater with the increasing of the vibration frequencies and in this way the rock acts as a fairly efficient low-pass filter (Hays, 1980).

To overcome or at least mitigate these limitations, it is possible to calculate and introduce frequencies that enrich the reflections that have been recorded, resampling the seismic signal, which caracterizes the geological layers and aid in the GC identification along the seismic sections. The sedimentar units or sequences, thus defined, bring together sets of reflections that have common peculiarities of the acoustic impedance of the geological column. In the present work, we propose the Low Frequency Enhancement (LFE) and High Frequency Enhancement (HFE) techniques.

The calculation of the frequencies that will be introduced in the seismic data is done by means of a spectral analysis of the existing frequencies in the data itself in the Hilbert Domain (Taner et al., 1979, Eqs. (1) and (2)). In other words, the complex seismic trace is calculated, and, in this domain, an analysis of the present frequencies is realized. After this analysis, an extrapolation was made for the harmonic and subharmonic frequencies, amplifying the seismic signal content for frequencies beyond the original bandwidth of the data, both for low and high frequencies (Fig. 2). An extrapolation was made for the harmonic and subharmonic frequencies based on a linear extrapolation of straight lines on the flanks of the first derivative reflectance spectrum.

The amplitude ratios, as well as the signal phase, are not altered, either in the lateral or in the vertical direction. Thus, it is possible to guarantee that this new processing step is reliable, brings good advantages in GC mapping and does not alter the seismic properties of the reflections in the seismic section.

$$
f^{*}(\tau)=\frac{1}{\pi} P . V \cdot \int_{-\infty}^{\infty} \frac{f(t)}{\tau-t} d t,
$$

where the integral of P.V. means the Cauchy principle value,

$$
\text { P.V. } \int_{-\infty}^{\infty} \lim _{n \rightarrow \infty}\left[\int_{-\infty}^{t-\varepsilon}+\int_{t+\varepsilon}^{+\infty}\right] \text {. }
$$

The processing methodology is performed trace by trace and can be applied at any stage of processing. As the purpose of this study was only to identify the gas chimneys, the methodology was applied in the final migrated seismic section, that is, the one that is by now ready for interpretation.

Figures 3 and 4 show a stretch from a seismic section containing gas chimneys and their frequency spectra for the 


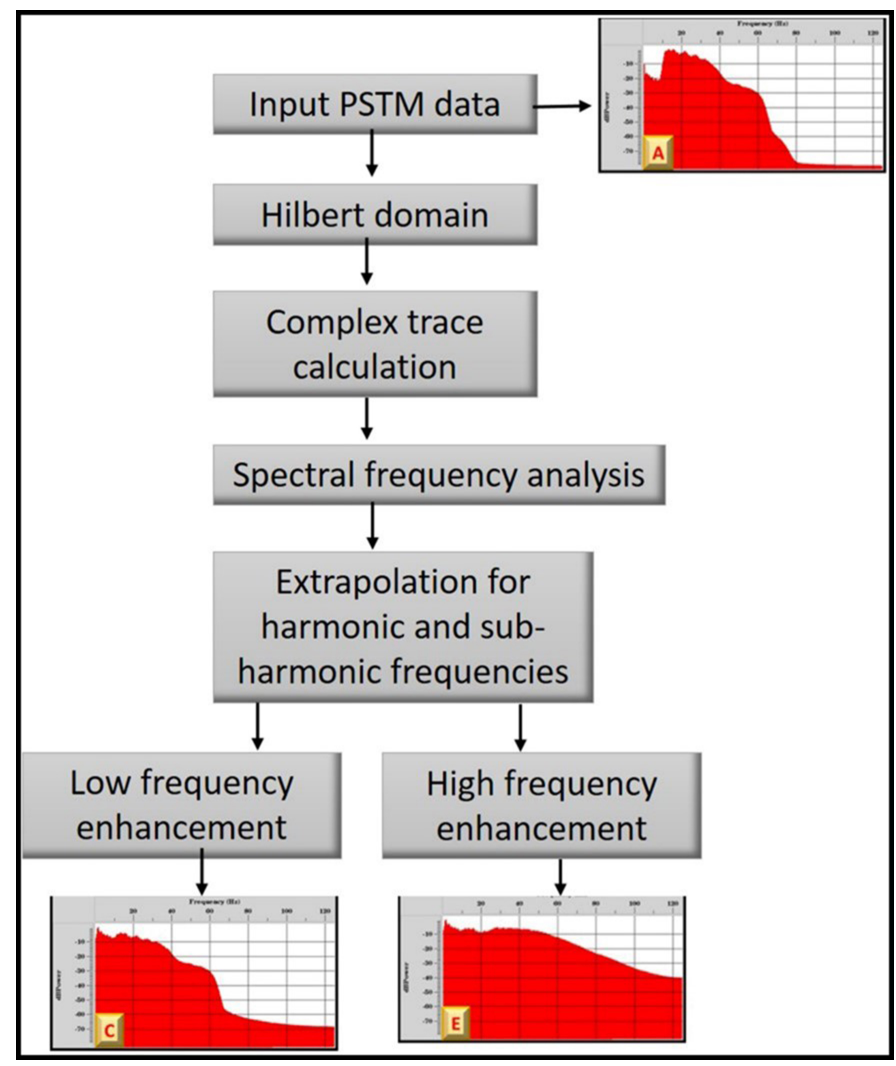

Figure 2 - Flow chart showing the processing sequence of the special processing applied to the seismic data.

original and filtered data with low (LFE) and high (HFE) frequency enhancements, respectively. The seismic data with standard seismic processing (PSTM) is shown in Figure 3. Note that the original seismic data has a frequency content centered between 10 and $40 \mathrm{~Hz}$, as shown in the frequency spectra. When applying the LFE filter it is possible to verify that the low frequencies have been added to the seismic data, since the frequency zero $\mathrm{Hz}$ (Fig. 4B). The effect of the addition of the low frequencies causes a relief aspect on the seismic data, as if the strongest reflection coefficients represented reflections with positive relief (leaving the plane of the section) (Fig. 4A). The application of the HFE filter promotes the enhancement of high frequencies, raising the spectral content of the seismic signal up to 70 $\mathrm{Hz}$ (Fig. 4D). The effect of extrapolating to high frequencies (Fig. 4C) is the compression of the wavelet, increasing the vertical resolution and allowing a better identification of reflector terminations when compared to the original section (Fig. 3A). Finally, Figure $4 \mathrm{E}$ shows the result of the enhancement of the low and high frequencies together in the seismic signal, whose frequency spectrum now varies from 0 to $70 \mathrm{~Hz}$ (Fig. 4F). The high relief aspect remains as in Figure 4A, but the reflections are more compressed. Thus, the seismic pattern of vertical zones of low amplitude is highlighted, allowing a more efficient identification of the gas chimneys.

The appearance of the seismic section filtered using the proposed technique (Fig. 4E) is close to the Amplitude Volume Technique (TecVA) response. However, the new methodology is not the same as TecVA attribute. Mainly because the data phase is almost perfectly preserved, such as the polarity of the reflections, while these two parameters are largely distorted in the TecVA attribute.

Figure 5 shows a comparison between a seismic section before and after the application of low frequency enhancement processing (LFE). One can observe that the seismic section in Figure $5 \mathrm{~B}$ allows much more precise and direct visualization of lateral discontinuities and the remarked loss of seismic signal, which indicate a $4.0 \mathrm{~km}$ wide and $1.2 \mathrm{~s} \mathrm{high} \mathrm{GC}$ in the right side of the seismic profile. The analysis of only the section shown in 


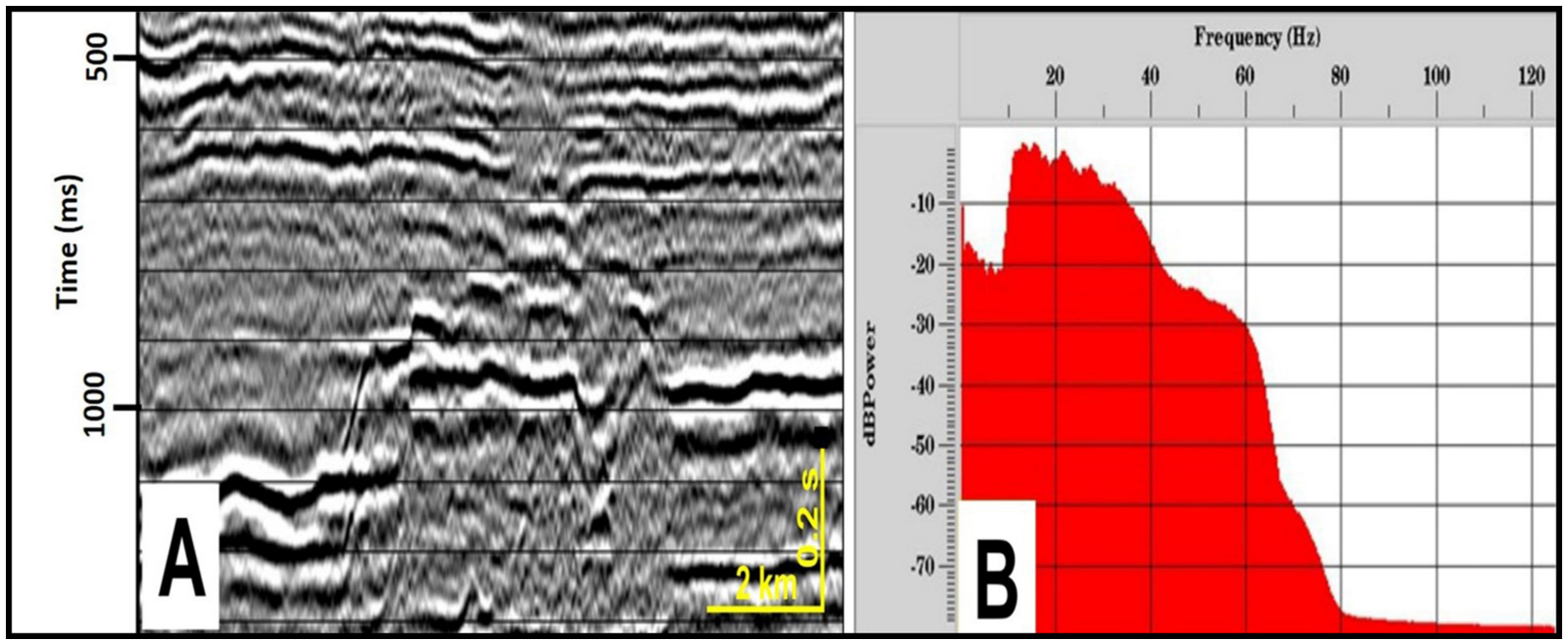

Figure 3 - Original seismic section showing the standard seismic processing, called Pre-Stack Time Migration, and its respective frequency spectrum.

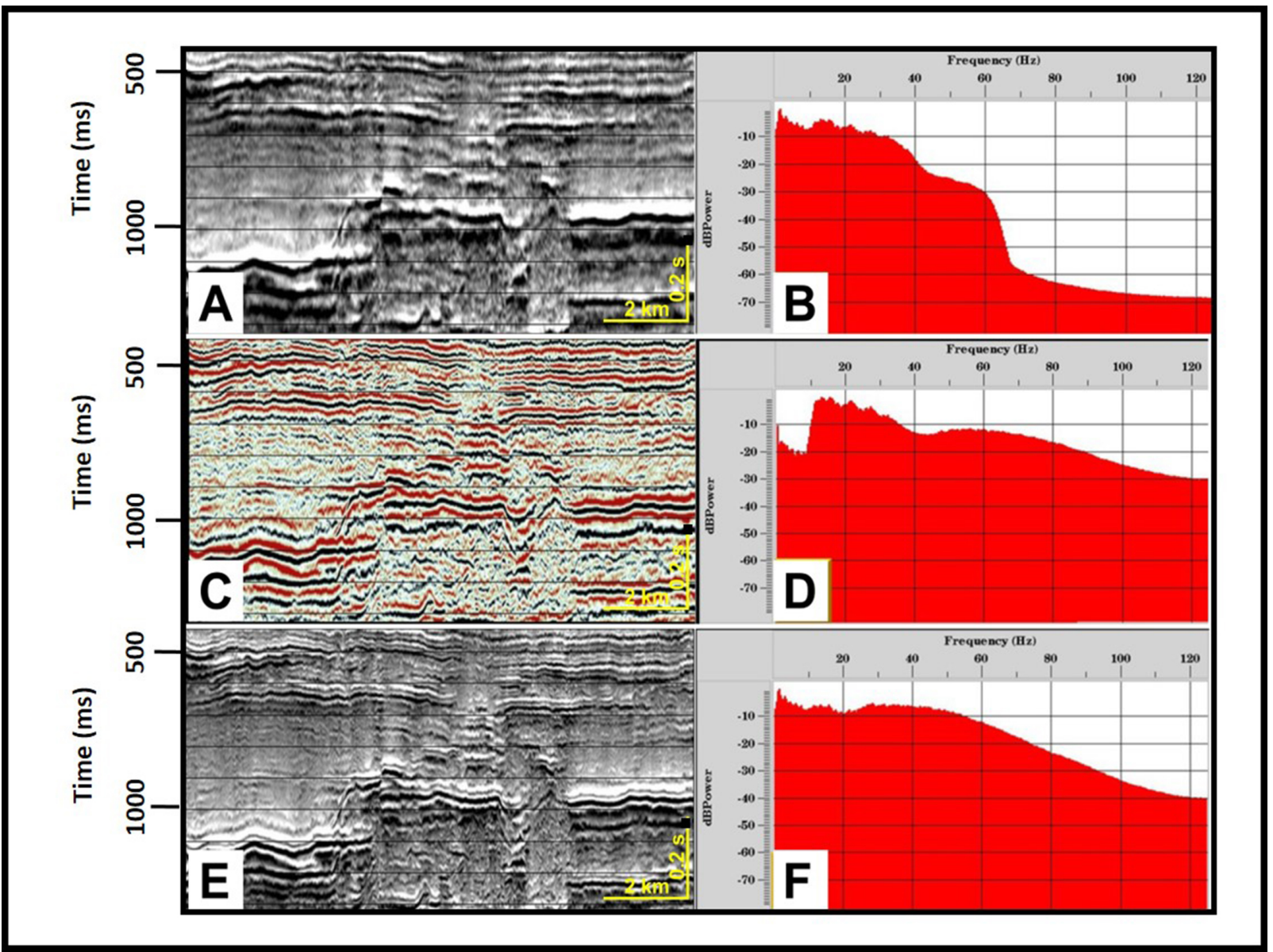

Figure 4 - Filtered seismic data with Low Frequency (A) and High Frequency (C) enhancement. The seismic section in E presents with emphasis of the Low and High Frequency filtering enhancement together. The respective frequency spectrums are shown in $B, D$ and $F$. 


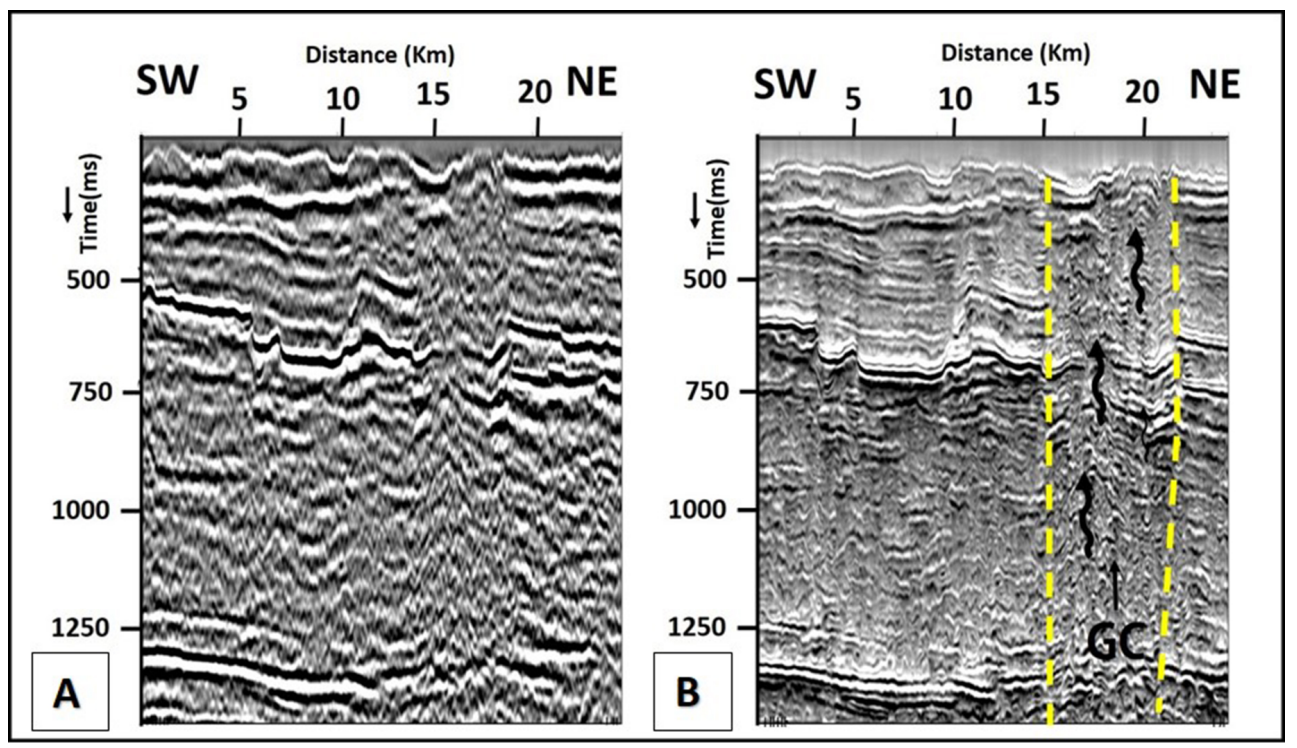

Figure 5 - A - Seismic section with standard processing (PSTM) and B - the result with the application of special processing for low frequency enhancement technique, highlighting the gas chimney (yellow dashed lines).

Figure $5 \mathrm{~A}$ would lead the interpreter to believe that there was a sudden loss of seismic quality in certain parts of the section, even raising questions about processing steps.

\section{Seismic Pattern of Gas Chimney and Associated Features}

A very large number of gas chimneys have passed and remained unnoticed in the seismic sections in several Brazilian sedimentary basins. The seismic section of the Parnaíba Basin, shown in Figure 5, is a good example of how this special processing can unambiguously reveal the gas chimney (GC). Currently in the Parnaíba Basin the GCs, dikes, the fracture zones associated with transcurrent events and mainly sill jumps are reviewed and interpreted as important exploratory objectives to be tested (Cunha et al., 2012). The systematic identification of this type of exploratory play increases, therefore, the number of exploratory opportunities in the basin and, consequently, the oil potential of the basin.

A large number of seismic and topographical features associated with gas chimneys was revealed by the processing and interpretation methodology described above. In sedimentary basins, the vertical migration of fluids and free gas through GCs causes distortions in the lateral continuity of the amplitudes and phase of the seismic reflections (Fig. 1) (Dangerfield, 1992; Heggland, 1997; Arntsen et al., 2007; Logan et al., 2008). Low amplitudes and low coherence mark its typical seismic response. GCs occur associated with gas escape features such as pockmarks, mounds, up-bending reflections (UBR), pull-down reflections and Hydrocarbon Related Diagenetic Zone (HRDZ). Pockmarks are crater-like depressions that occur on the surface in varied forms, mostly elliptic or rounded, usually in soft, fine grained sediments (Loseth et al., 2009) that vary in terms of sedimentary environment from the slope and continental shelf to estuaries and lacustrine environments (Webb, 2009). Its origin is related to the explosive or continuous escape of gas in the surface, generating the topographic lows that characterize this feature. In the seismic sections, the pockmarks are located mainly above the GCs (Virs, 2015) (Fig. 6). Figure 6 also shows a flat event (FE), which occurs at the apex of a set of reflections to the left part of the section, characteristic of zones of contact between accumulations of hydrocarbons (gas/oil) or between different fluids (hydrocarbon/water). The presence of FE reinforces the possibility of the pockmark to have its generation associated with GCs nearby.

Cementation processes can generate topographic highs associated with GCs, which are known in the literature as mounds (Hovland et al., 1994; Naeth et al., 2005). These elevations are formed by banks of biogenic carbonates or carbonate-cemented sandstones, usually located on regions where hydrocarbon accumulation is associated with faulting (Logan et al., 2008) (Fig. 7). In the record of tectono-sedimentary sequences deposited over geological time, mounds with similar 


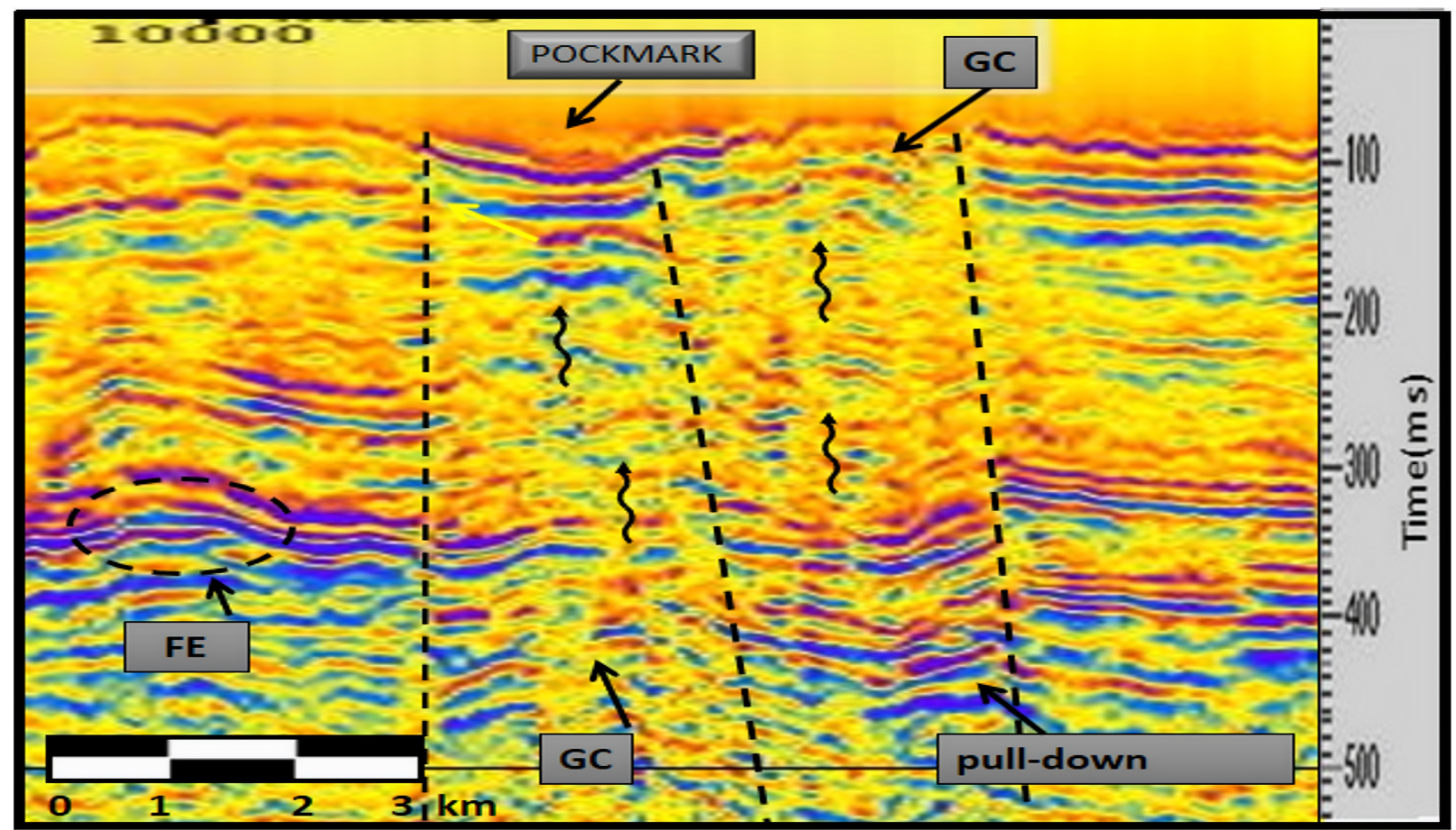

Figure $\mathbf{6}$ - Seismic section with special processing showing gas chimneys (GC) and pockmark on the surface. Reflectors with time pull-down at the GC base indicate a decrease in seismic velocity due to the presence of gas. FE= flat event.

characteristics have been described from the Miocene of the Piedmont Basin in northern Italy, through the carbonate mounds of the Cretaceous-Campanian of Colorado (USA), and in the Jurassic sedimentary sequences of the Southeastern Basin in France (Moore \& Wade, 2001). Many oil and gas wells in the onshore basins are located beneath the topographic highs associated with gas chimneys, because they are more resistant to erosion in face of the increase of cementation on the reservoirs (Saunders et al., 1999).

Up-bending reflections are the result of mechanical deformation due to upward leakage of the fluids or may be only an artifact generated by the velocity field, since a progressive increase of the seismic velocity in the direction of the GC center occurs (Westbrook et al., 2008; Plaza-Faverola et al., 2010) (Fig. 7). However, pull-down reflections are often seen as low velocity zones associated with interstitial gas (Logan et al., 2008) (Fig. 6).

HRDZs are formed when hydrocarbons escape from reservoirs, through fault reactivations, and trapped in normally sandy aquifers. Then they are biodegraded by the bacteria action, producing an intense carbonate cementation which, in turn, is responsible for the seismic amplitude anomalies in the upper part of the feature (Cowley \& O'Brien, 2000). Among its main characteristics observed, in addition, there are up-bending reflections (Fig. 7) and also the same chaotic, low amplitude column of events typical of gas chimneys (Fig. 8).

\section{Transbrasiliano Lineament, Thermogenic Anomalies and Gas Chimneys}

According to De Castro et al. (2016), the Transbrasiliano Lineament (TL) controlled the formation of an extensive Cambrian-Ordovician rift zone in the eastern portion of the Parnaíba Basin. Subsequent reactivations deformed post-rift tectono-sedimentary sequences (Fig. 9), including post-Devonian tectonic inversions (Destro et al., 1994). In the studied region, thermogenic anomalies were identified based on surface geochemical data acquired by the Agência Nacional do Petróleo, Gás Natural e Biocombustíveis - ANP (Brazilian Petroleum Agency) and it was found that they coincide with gas chimney and also with the presence of transcurrent faults belonging to the TL, reactivated in the Cenozoic (Fig. 9).

\section{Geochemical Sampling}

By facilitating the mapping of the gas chimneys, the proposed seismic processing also helps to optimize the process of 


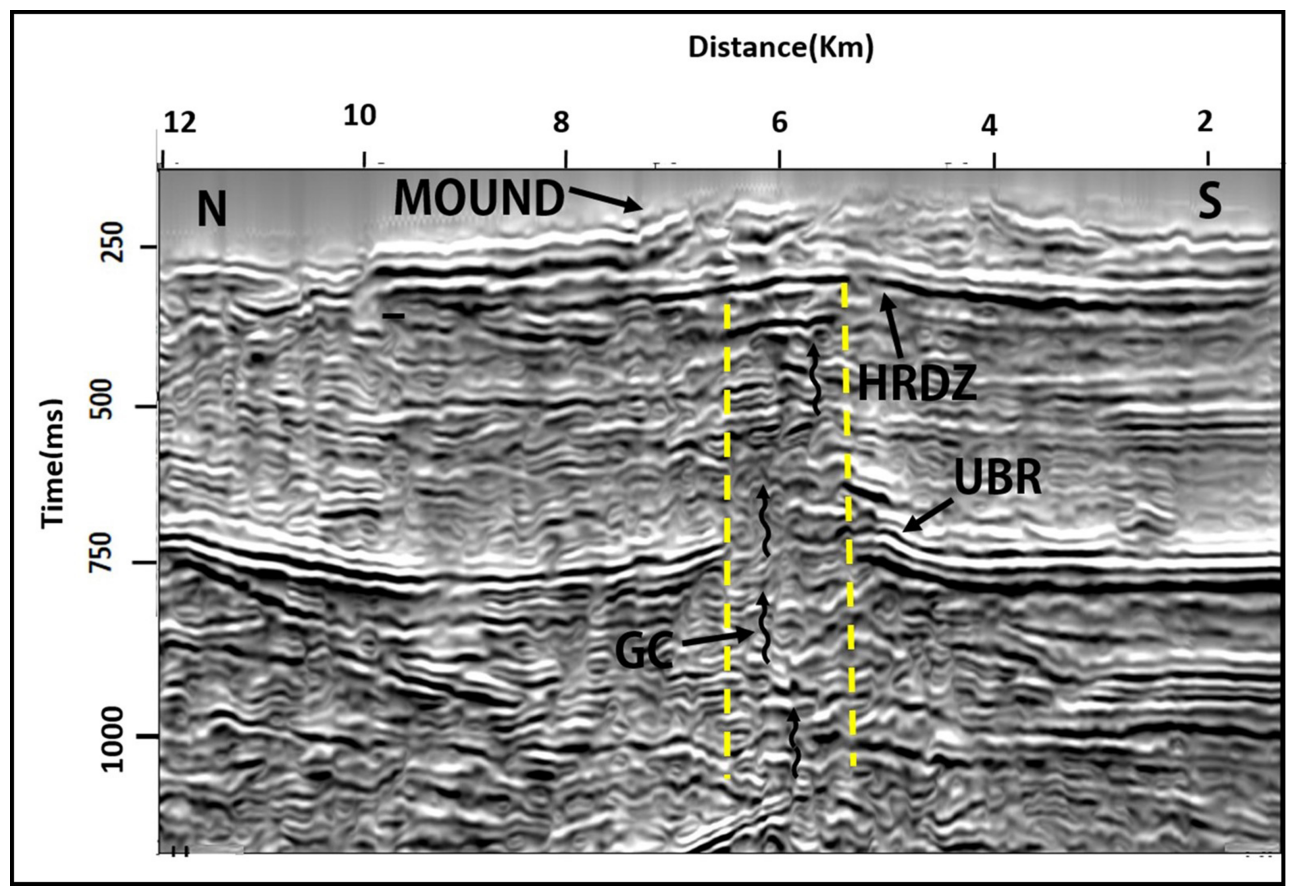

Figure 7 - Seismic section with special processing showing gas chimney (GC) associated to a high topographic (mound). Typical seismic patterns of GC can be observed as: Ioss of lateral continuity of reflections with signal degradation, Hydrocarbon Related Diagenetic Zone (HRDZ) and up-bending reflections (UBR).

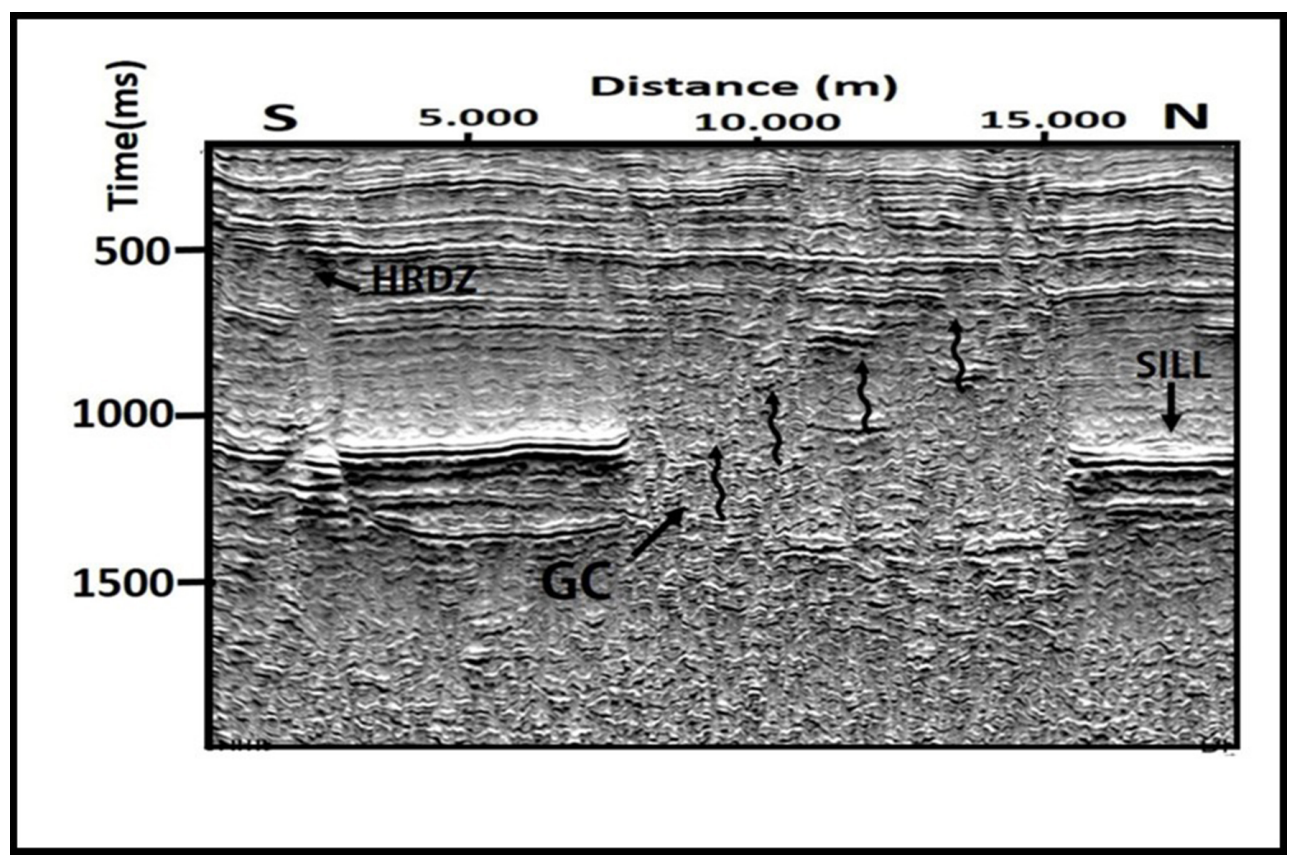

Figure 8 - Seismic section after special processing (LFE), highlighting the typical seismic pattern of a gas chimney (GC) in an area with sill jumps and Hydrocarbon Related Diagenetic Zone (HRDZ). 


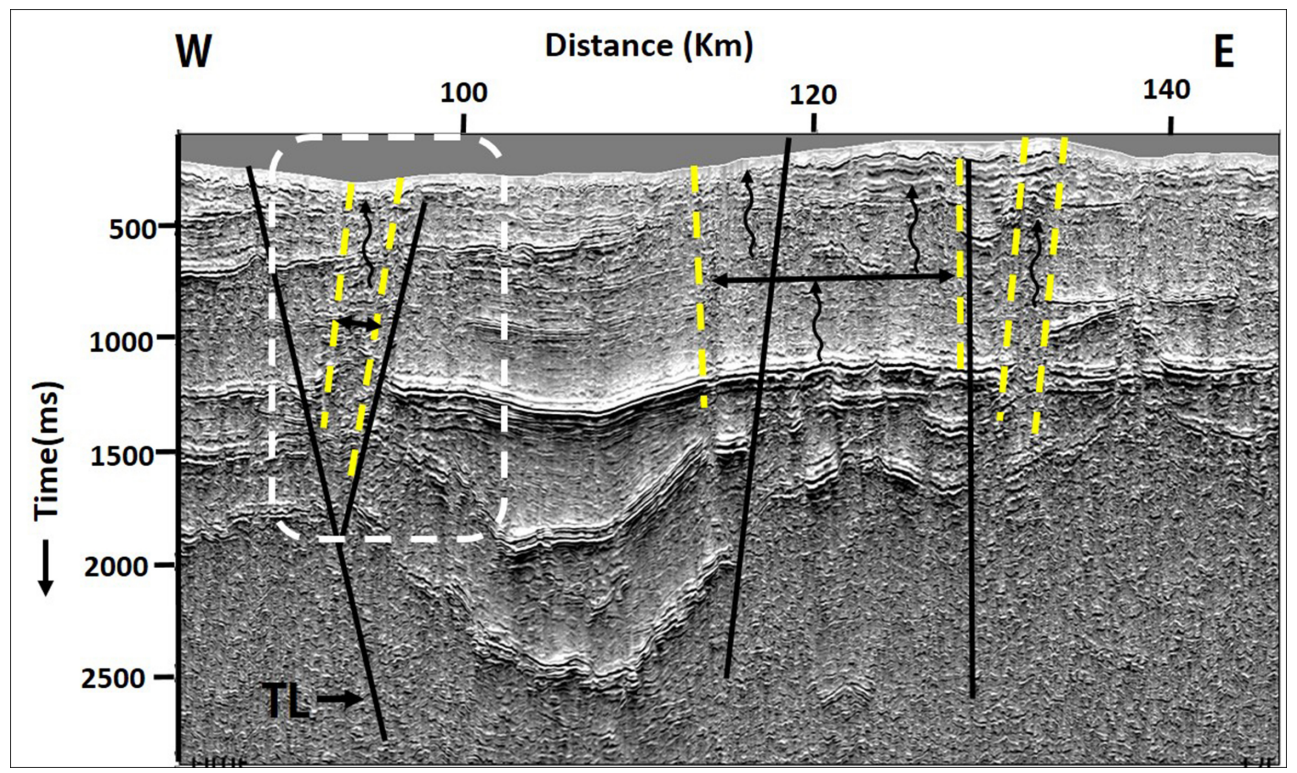

Figure 9 - Seismic section with the special processing in the Parnaíba Basin, with gas chimneys (yellow dashed lines) showing a good correlation with the Transbrasiliano Lineament faults $(\mathrm{TL})$ and the thermogenic anomaly (white dashed line, according to Alves, 2013).

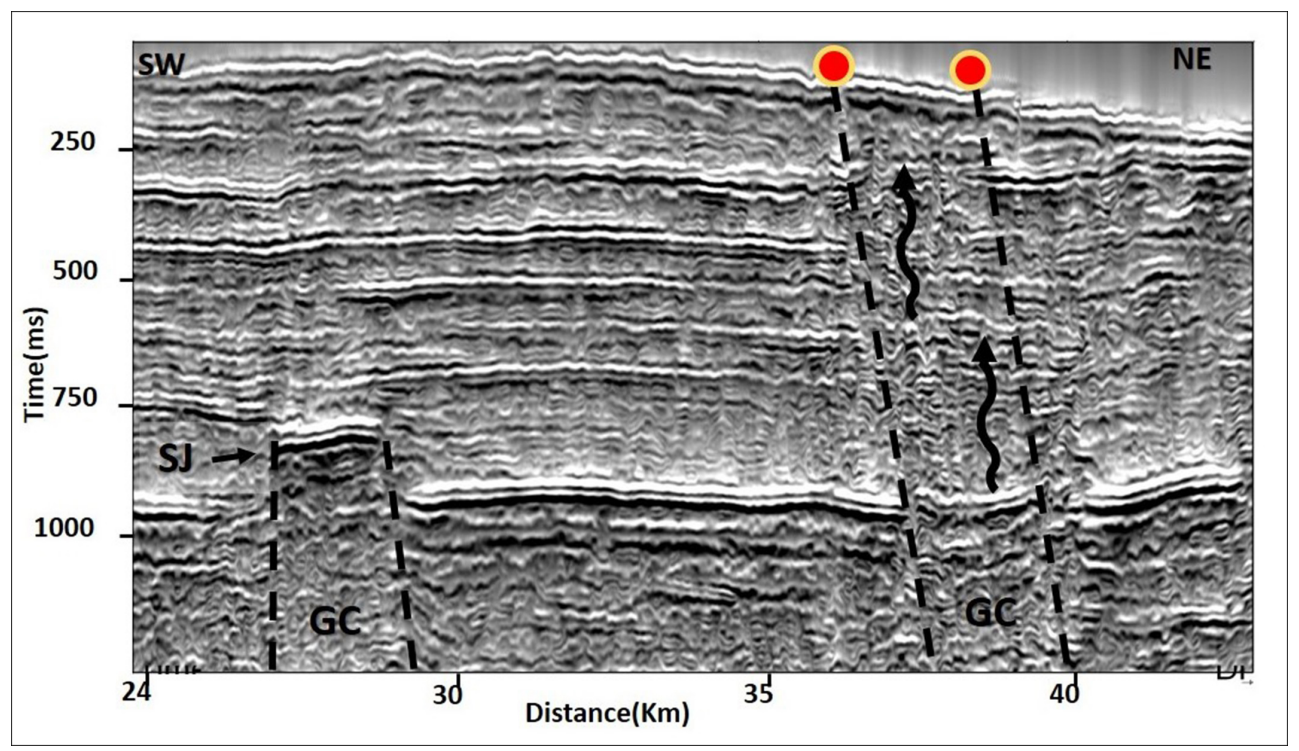

Figure 10 - Seismic section with special processing crossing a structural high, flanked by two gas chimneys. One with top marked by a sill jump (SJ - left flank), and the other extending up to the surface (right flank). Red circles are the suggested locations for geochemical sampling. 
choosing the geochemical sampling points on the surface (Fig. 10). This is a relevant subsidy to the exploratory process in the Parnaíba Basin, since, in this way, by evaluating the points where the gas chimneys reach the surface, the probability to have associated thermogenic anomalies are high (Sechman et al., 2014).

\section{DISCUSSION}

The systematic application of this processing methodology in the various sedimentary basins with gas chimneys will create an important procedure for the identification, mapping, study and utilization of gas chimneys as an exploratory tool, mainly in the frontier basins where the understanding of the petroleum system becomes fundamental along with the consequent reduction in exploratory risks.

The tectono-sedimentary setting of the studied area suggests that the faults associated to the TL served as preferred conduits for the migration of the hydrocarbons, thus forming this large amount of gas chimneys. In fact, according to Connolly et al. (2008), faulting systems, when reactivated in transcurrent tectonic regimes, can create expansions along releasing bendings of strike-slip faults, which would be potential paths for migration of hydrocarbons and thus generate the gas chimneys, such as those observed in the seismic section (Figs. 5 to 10).

The observed seismic and topographic features associated with the gas chimneys served to validate the performed seismic interpretations. In addition, HRDZs are important in oil prospecting because they indicate the existence of nearer, deeper accumulations of hydrocarbons, and also because they are a reliable parameter in exploratory risk assessment, particularly with respect to hydrocarbon trap saturation and whether the fault is sealant or not (Cowley \& O'Brien, 2000). HRDZs are also enhanced by the proposed seismic processing.

Thermogenic anomalies are due to the rise of hydrocarbons, especially in the gaseous form, to the surface. Therefore, an adequate mapping of gas chimneys in seismic data, provided by special processing, can be used to guide surface geochemical surveys.

\section{CONCLUSIONS}

The application of special low frequency (LFE) and high frequency (HFE) enhancement processing highlights very well the typical seismic patterns of gas chimneys when compared to the results of standard seismic workflow (PSTM). As the identification and mapping of these structures is facilitated, the seismic processing and interpretation procedures gain a greater reliability. It is therefore essential for those who work as processors and interpreters of seismic sections to know the precise location of the gas chimneys in their areas, thus avoiding that they are treated as noises and seek its elimination from the seismic data. The new methodology introduces frequencies to the seismic data that enrich the recorded reflections, highlighting the lateral contrasts of acoustic impedance between the chaotic events of the gas chimneys and the continuous and stratified reflections of the host rocks. The sedimentary sequences, thus defined, bring together sets of reflections that have common peculiarities of the acoustic impedance of the geological layers. These features enhanced by the proposed processing may also indicate possible hydrocarbon migration routes until they are trapped at the sill jumps with trap integrity.

The presence of the gas chimneys, identified with the application of special processing, was confirmed by the observation of correlated topographic features such as pockmarks and mounds. Other seismic patterns associated with gas chimneys were also identified. These are: Hydrocarbon Related Diagenetic Zone (HRDZ), up-bending and pull-down reflections. Finally, gas chimneys mapped in seismic sections in the Parnaíba Basin, perpendicular to the Transbrasiliano Lineament, are coincident with thermogenic anomalies, detected with surface geochemical data. Therefore, gas chimneys trapped by sills, sill jumps, and dikes can really be considered important exploratory plays in the Parnaíba Basin. In addition, gas chimneys, when clearly mapped to the surface, are highly recommended points for geochemical sampling.

By revealing the presence of numerous gas chimneys in seismic sections, this methodology was able to increase the exploratory potential and, consequently, reduce the high exploratory risks inherent from frontier basins such as the Parnaíba Basin. Gas chimneys should no longer be seen as undesirable noises in the seismic section but rather as signals belonging to a new technique of great help in the exploration of hydrocarbons.

\section{ACKNOWLEDGMENTS}

The authors would like to thank Global Serviços Geofísicos Ltda. for allowing the use of the lines acquired by this company and the Central de Imageamento Geofísico (CIMAGEO) for the special processing performed in the seismic data and permission to present them in this study. DLC thanks CNPq for his $\mathrm{PQ}$ grants. 


\section{REFERENCES}

ALVES MAR. 2013. Bacia do Parnaíba. Seminário Técnico da $11^{a}$ Rodada de Licitações. Available on: <http://rodadas.anp.gov.br/arquivos/ Round11/Seminarios_r11/tec_ambiental/Bacia_do_Parnaiba.pdf $>$. Accessed on: October 27, 2018. 76 pp.

AMINZADEH F, BERGE T, VALENTI G \& GRO0T P. 2001. Gas Chimney: An effective Exploration Tool. Word Oil, 222: 50-56.

AMINZADEH F, GROOT P \& CONNOLLY DL. 2002. Interpretation of Gas Chimney Volumes. In: SEG 72nd Exposition and Annual Meeting. Salt Lake City, Utah. Expanded Abstracts.

ARNTSEN B, WENSAAS L, LOSETH H \& HERMANRUD C. 2007. Seismic Modeling of Gas Chimney. Geophysics, 72(5): 251-259.

BHANDARI SK \& CIVIDIN R. 2008. Improving seismic resolution through high frequency imaging. In: 7th Biennal International Conference \& Exposition on Petroleum Geophysics. SPG-Society of Petroleum Geophysicist, Hyderabad, India, 6 pp.

BULHÕES EM \& AMORIM WN. 2005. Princípio da SismoCamada Elementar e sua aplicação à Técnica Volume de Amplitudes (tecVA). In: 9th International Congress of the Brazilian Geophysical Society. Salvador. Brazil, SBGf, Expanded Abstracts: 1382-1387.

CONNOLLY DL, BROUWER F \& WALRAVEN D. 2008. Detecting Fault-Related Hydrocarbon Migration Pathways in Seismic Data: Implications for Fault-Seal, Pressure and Charge Prediction. GCAGSTGulf Coast Association of Geological Societies Transactions, 58: 191-203.

CORDANI UG, BRITO NEVES BB \& THOMAZ FILHO A. 2009. Estudo preliminar de integração do Pré-Cambriano com os eventos tectônicos das bacias sedimentares brasileiras (Atualização). Boletim de Geociências da Petrobras, Rio de Janeiro, Petrobras, 17(1): 205-219.

COWLEY R \& O'BRIEN GH. 2000. Identification and Interpretation of leaking hydrocarbon using seismic data: A comparative montage of examples from major fields in Australia northwest shelf and Gippsland Basin. The APEA Journal, 40(1): 121-150.

CUNHA PRC, BIANCHINI AR, CALDEIRA JL \& MARTINS CC. 2012. Parnaíba Basin - The Awakening of a Giant. In: XI Simposio Bolivariano de Exploración Petrolera en las Cuencas Subandinas. Cartagena de Indias, Colombia, Extended Abstract, Asociación Colombiana de Geólogos e Geofísicos del Petroleo.

DANGERFIELD JA. 1992. Ekofisk field development: Making images of a gas obscured reservoir. In: SHERIFF RE (Ed.). Reservoir geophysics. SEG: 98-109.

DE CASTRO DL, FUCK RA, PHILLIPS JD, VIDOTTI RM, BEZERRA FH \& DANTAS EL. 2014, Crustal Structure beneath the Paleozoic Parnaíba Basin revealed by Airborne Gravity and Magnetic Data, Brazil. Tectonophysics, 614: 128-145.
DE CASTRO DL, BEZERRA FH, FUCK RA \& VIDOTTI RM. 2016. Geophysical Evidence of Pre-Sag Rifting and Post-Rifting fault Reactivation in the Parnaíba Basin, Brazil. Solid Earth, 7: 529-548.

DESTRO N, SZATMARI P \& LADEIRA EA. 1994. Devonian transpressional reactivation of a Proterozoic ductile shear zone in Ceará, NE Brazil. J. Struct. Geol., 16: 35-45.

DUNBAR T, HOFLAND G \& DAVIS B. 1998. 3D Depth Imaging Through a Gas Cloud Using a Phased Velocity Modelling Approach. In: 60th EAGE Conference and Exhibition. European Association of Geoscientists \& Engineers, Leipzig, Germany. Session: 01-04.

ENGLEHART T, RANDAZZO S, BERTAGNE A \& CAFARELLI B. 2001. Interpretation of four component seismic data in a gas cloud area of the central Gulf of Mexico. The Leading Edge, 20(4): 400-408.

HAYS WW. 1980. Procedures for estimating earthquake ground motions. U.S. Geological Survey. Professional Paper 1114, 92 pp.

HEGGLAND R. 1997. Detection of Gas Migration from a Deep Source by the use of exploration 3D Seismic Data. Marine Geology, 137: 41-47.

HEGGLAND R. 1998. Gas seepage as an indicator of deeper prospective reservoirs. A study based on exploration 3D seismic data. Mar. Petrol. Geol., 15: 9 pp.

HOVLAND M, CROKER PF \& MARTIN M. 1994. Fault Associated Seabed Mounds (Carbonate Knolls?) off Western Ireland and North-West Australia. Marine and Petroleum Geology, 11(2): 232-246.

LIGTENBERG JH. 2005. Detection of fluid migration pathways in seismic data: implications for fault seal analysis. Basin Research, 17: 141-153.

LOGAN GA, JONES AT, RYAN GJ, WETTLE M, THANKAPPAN M, GROSJEAN E, ROLLET N \& KENNARD JM. 2008. Review of Australian Offshore Natural Hydrocarbon Seepages Studies. Book from Geoscience Australian Record, $235 \mathrm{pp}$.

LOSETH H, GADING M \& WENSAAS L. 2009. Hydrocarbon leakage interpreted on seismic data. Mar. Petrol. Geol., 26(7): 1304-1319.

MESNER JC \& WOOLDRIDGE LC. 1964. Maranhão Paleozoic Basin and Cretaceous Coastal Basins, North Brazil. AAPG Bulletin, 48(9): 1475-1512.

MOORE CH \& WADE WJ. 2001. Carbonate Reservoirs- Porosity evolution and Diagenesis in a Sequence Stratigraphic Framework. Elsevier Ltd., 2nd ed., Part 1, Chapter 2, 34 pp.

NAETH J, PRIMIO R, HORSFIELD B, SCHAEFER RG, SHANNON PM, BAILEY WR \& HENRIET JP. 2005. Hydrocarbon seepage and carbonate mound formation: A Basin Modelling Study from the Porcupine Basin (offshore Ireland). Journal of Petroleum Geology, 28(2): 147-166.

PLAZA-FAVEROLA A, WESTBROOK GK, KER S, EXLEY R, GAILLER A, MINSHULL TA \& BROTO K. 2010. Evidence from three-dimensional 
seismic tomography for a substantial accumulation of gas hydrate in a fluid-escape chimney in the Nyegga pockmark field, offshore Norway. J. Geophysical Research, 115: 24 pp.

SAUNDERS DF, BURSON KF \& THOMPSON CK. 1999. Model for hydrocarbon seepage and its related near-surface alterations. AAPG Bulletin, 83: 170-185.

SECHMAN H, PIETSCH K, POREBSKI SJ, MARZEC P, IZYDOR G \& GUZI P. 2014. Gas chimney record in seismic and surface geochemical dataCase study from the Carpathian Foredeep (SE Poland). In: 76th EAGE Conference \& Exhibition. Amsterdam, Netherlands. 6 pp.

TANER MT, KOEHLER F \& SHERIFF RE. 1979. Complex seismic trace analysis. Geophysics, 44(6): 1041-1063.
VIRS R. 2015. Comparative seismic study of gas chimney structures from active and dormant seepages sites offshore mid-Norway and west-Svalbard. The Artic University of Norway, Master Thesis in Geology, $141 \mathrm{pp}$.

WEBB KE. 2009. Ecology and Geology of Pockmarks. PhD Dissertation, Faculty of Mathematics and Natural Sciences, Oslo University, 43 pp.

WESTBROOK GK, EXLEY R, MINSHULL T, NOUZE H, GAILLER A, JOSE

T \& PLAZA A. 2008. High-Resolution 3D Seismic Investigations of Hydrate-bearing fluid-escape chimneys in Nyegga Region of the Vøring Plateau, Norway. In: Proceedings of the 6th International Conference on Gas Hydrates. University of British Columbia, Vancouver, Canada, 12 pp.

Recebido em 1 de março de 2019 / Aceito em 4 de dezembro de 2019

Received on March 1, 2019 / Accepted on December 4, 2019 